\title{
MEMPELAJARI PEMANFAATAN AIR CUCIAN BERAS (Leri) PADA PROSES PEMBUATAN NATA DE LERI
}

\author{
Learn utilization of rice washing (leri) at process production nata de leri
}

\author{
M. Faiz Al Laily ${ }^{1}$, Hapsari Titi palupi ${ }^{1}$ \\ ${ }^{1}$ Ilmu dan Teknologi Pangan, Fakultas Pertanian, Universitas Yudharta Pasuruan \\ Email : faizallaily29@gmail.com
}

\begin{abstract}
Due to its high nutrition, leri has a big potency to become bacterial growth media and nata. The study aims to find out the influence of coconut sugar concentration and the starter Acetobacter xylinum on the physical and chemical quality of nata de leri product. The research employs an experimental study using two factor, Factor 1 proportion that consist of four variable treatment, and each treatment was repeated three times. Proportion of washing rice (leri) 0\%: water coconut 100\% proportion of whasing $25 \%$ : water coconut $75 \%$ proportion washing rice $50 \%$ : water coconut $50 \%$ proportion washing rice $100 \%$ : water coconut $0 \%$. The data analysis uses ANOVA. If it has a significant difference with a confidence interval $5 \%$ and $1 \%$, if found influence on one of variable then continued with test of real small difference (BNT) $5 \%$. Observations were performed with the best proportion of rice water and coconut water from physical properties with the result of nata de leri thickness test analysis at treatment ( $75 \%$ coconut water and $25 \%$ rice wash water) with $9.05 \mathrm{~mm}$ thickness value. The best proportion of rice and coconut rice water from organoleptic properties with effectiveness index test was found in treatment $(75 \%$ coconut water and $25 \%$ washing rice), 2,25 (somewhat like), aroma with value 2.50 (likes), color with a value of 2.40 (like). The best proportion of rice and coconut rice water from physical and organoleptic properties with effectiveness index test was found in treatment $175 \%$ coconut water and 25\% rice wash water), 2,25 (somewhat like), aroma with value 2.50 ( likes), color with a value of 2.40 (like).
\end{abstract}

Keywords : Water formerly washing RICE (Leri), Nata De Leri

\begin{abstract}
ABSTRAK
Karena nutrisi yang tinggi, leri memiliki potensi besar untuk menjadi media pertumbuhan bakteri dan nata. Penelitian ini bertujuan untuk mengetahui pengaruh konsentrasi gula kelapa dan starter Acetobacter xylinum terhadap kualitas fisik dan kimia produk nata de leri. Penelitian ini menggunakan penelitian eksperimental dengan menggunakan dua faktor, proporsi Faktor 1 yang terdiri dari empat perlakuan variabel, dan setiap perlakuan diulang tiga kali. Proporsi pencucian beras (leri) 0\%: kelapa air 100\% proporsi kekalahan 25\%: kelapa air 75\% proporsi pencucian beras 50\%: air kelapa 50\% proporsi pencucian beras 100\%: air kelapa 0\%. Analisis data menggunakan ANOVA. Jika memiliki perbedaan signifikan dengan interval kepercayaan 5\% dan $1 \%$, jika ditemukan pengaruh pada salah satu variabel maka dilanjutkan dengan uji beda nyata nyata (BNT) 5\%. Pengamatan dilakukan dengan proporsi air beras dan air kelapa terbaik dari sifat fisik dengan hasil analisis uji ketebalan nata de leri pada perlakuan (75\% air kelapa dan 25\% air pencuci beras) dengan nilai ketebalan 9,05 mm. Proporsi terbaik beras dan air beras kelapa dari sifat organoleptik dengan uji indeks efektivitas ditemukan dalam perlakuan (75\% air kelapa dan 25\% mencuci beras), 2,25 (agak mirip), aroma dengan nilai 2,50 (suka), berwarna dengan nilai 2,40 (seperti). Proporsi terbaik beras dan air beras kelapa dari sifat fisik dan organoleptik dengan uji indeks
\end{abstract}


efektivitas ditemukan dalam perlakuan (75\% air kelapa dan $25 \%$ air pencuci beras), 2,25 (agak mirip), aroma dengan nilai 2,50 (suka), warna dengan nilai 2,40 (seperti).

Kata kunci: AIR bekas mencuci BERAS (Leri), Nata De Leri

\section{PENDAHULUAN}

Nata merupakan makanan yang banyak dikonsumsi dan disukai oleh masyarakat terutama untuk campuran makanan penyegar atau pencuci mulut (dessert) seperti es, es krim jelly, dll. Bahkan untuk penyediaan industri makanan, kebutuhan nata sangat besar. Nata memiliki kelebihan yaitu mempunyai nilai gizi yang baik karena kaya kandungan serat makanan yang dibutuhkan oleh sistem pencernaan tubuh. Nata adalah kumpulan selulosa yang mempunyai tekstur kenyal, putih, menghasilkan lembaran gel dan terapung pada bagian permukaan cairan (Arviyanti, 2009). Bahan yang dapat digunakan sebagai media untuk pembuatan nata adalah air kelapa sehingga produknya dikenal dengan nata de coco. Selain itu bahan lainnya adalah sari nanas (nata de pina), kedelai (nata de soya) singkong (nata decassava) atau buah lain yang mengandung glukosa. Mikroba yang aktif dalam pembuatan nata adalah baketri pembentuk selulosa yaitu Acetobacter Xylinium (Nur, A, 2009).

Air cucian beras termasuk salah satu limbah organik yang keberadaannya sangat melimpah dan mudah didapat. Selain itu air cucian beras memiliki kelebihan yaitu mengandung karbohidrat untuk sumber karbon, vitamin dan mineral yang cukup banyak. Menurut Rachmat (2007), air cucian beras memiliki kandungan karbohidrat, protein, serta vitamin B yang terdapat pada pericarpus dan aleuron yang ikut terkikis. Dalam pemanfaatannya, air cucian beras telah digunakan sebagai pupuk organik bagi tanaman dan media pertumbuhan bakteri mengingat kandungan karbohidrat dan vitaminnya yang dapat berperan dalam metabolism dan dapat dikonversikan menjadi energi untuk aktivitasnya. Air cucian beras juga memiliki kesamaan dengan air kelapa mengingat kendungan karbohidratnya yang berperan sebagai yang dilakukan oleh Fitriah (2009) membuktikan bahwa besarnya kandungan karbohidrat dan zat-zat lain didalam air cucian beras membuatnya berpotensi sebagai untuk pembentukan selulosa (nata).

Berdasarkan penelitian Rachmat (2007) juga menjelaskan bahwa air cucian beras dapat dijadikan bahan tambahan (fortifikator) dalam fermentasi nata de coco. Hasil penelitian menghasilkan nat de coco yang lebih tebal dibandingkan yang terbuat dari air kelapa saja. Hal ini disebabkan air cucian beras mengandung vitamin dan gizi yang diperlukan dalam metabolisme sel mikroba.Thiamin yang terkandung air cucian beras membantu mikroba dalam pelepasan energy, asam aminonya membantu regulasi metabolit, sedangkan lisin berperan dalam $\beta$ oksida asam lemak. Berdasarkan pemikiran diatas maka perlu dilakukan penelitian mengenai pemanfaatan air cucian beras (leri) pada proses pembuatan nata de leri.

\section{METODE PENELITIAN}

Bahan-bahan yang digunakan dalam penelitian antara lain : Air cucian beras (leri), ammonium sulfat, asam asetat, $\mathrm{H}_{2} \mathrm{SO} 4$, fenol Kristal, glukosa standar, starter bakteri Acetobacter xylinum, dan gula tebu.

Alat -alat yang digunakan dalam penelitian ini antara lain : timbangan analitik, nampan plastik, kompor, panic stainless steel, pengaduk, gelas beker, tabung reaksi, mikropipet, labu ukur, kertas Koran, karet, kertas $\mathrm{pH}$, kertas label, pisau dan jangka sorong.

Penelitian ini merupakan penelitian eksperimental yang dilakukan dengan menggunakan Rancangan Acak Kelompok (RAK) faktor tungal yang terdiri dari 4 
variabel perlakuan, dan masing-masing perlakuan diulang sebanyak 3 kali.

$\mathrm{X}_{1}=$ proporsi air cucian beras $0 \%$ : air kelapa $100 \%$

$\mathrm{X}_{2}=$ proporsi air cucian beras $25 \%$ : air kelapa75\%

$\mathrm{X}_{3}=$ proporsi air cucian beras $50 \%$ : air kelapa50\%

$\mathrm{X}_{4}=$ proporsi air cucian beras $100 \%$ : air kelapa $0 \%$

Proses pembuatan nata de leri adalah sebagai berikut : Air cucian beras sesuai perlakuan (1L) disaring menggunakan kain kasa untuk menghilangkan kotoran yang ikut dalam proses pencucian beras. Selanjutnya pencampuran bahan yaitu air cucian beras (sesuai perlakuan/ $1 \mathrm{~L}$ ), urea $(10 \mathrm{~g})$ sebagai sumber nitrogen dan gula $(100 \mathrm{~g})$.kemudian di rebus hingga mendidih, sesekali dilakukan pengadukan,Penambahan asam asetat $100 \mathrm{ml}$ dilakukan hingga $\mathrm{pH}$ media mencapai 4,0 untuk pertumbuhan bakteri starter yang optimum. Media yang sudah direbus dimasukkan ke dalam nampan dan ditutup dengan koran, kemudian didinginkan dalam suhu ruang. Proses berikutnya adalah inokulasi starter Acetobacter xylinum $100 \mathrm{ml}$.

Proses fermentasi, nampan yang digunakan disusun dan diletakkan ditempat yang bebas dari getaran. Bahan yang digunakan sebagai penutup nampan adalah kertas berwarna coklat yang diikatkan dengan karet disekeliling bibir nampan.

Proses fermentasi selama 15 hari, dilakukan pengamatan ketebalan pada hari ke 15 .

\section{Metode Pengumpulan Data}

Metode pengumpulan data yang di gunakan pada penelitian ini dengan melakukan pengamatan meliputi analisa fisik dan organoleptik. fisik yaitu ketebalan nata organoleptik yaitu warna, tekstur, aroma yang merupakan uji hedonik kesukaan.

\section{Metode Analisa Data}

Analisa data dilakukan secara ANOVA dengan selang kepercayaan 5\% dan $1 \%$ apabila ditemukan pengaruh terhadap salah satu variable maka dialnjutkan dengan uji beda nyata terkecil (BNT) $5 \%$.

Untuk uji organeleptik menggunakan uji Fridman. Perlakuan terbaik menggunakan metode indeks efektifitas de Garmo et al., (1984) yang dimodifikasi oleh Susrini (2005).

\section{HASIL DAN PEMBAHASAN}

\section{Analisa ketebalan nata de leri}

Berdasarkan hasil pengukuran ketebalan dengan pengamatan setelah hari ke-15 diketahui bahwa ketebalan yang terkecil pada perlakuan $\mathrm{X} 4=$ proporsi air cucian beras $100 \%$ : air kelapa 0\% ketebalan rata-rata sebesar $5,93 \mathrm{~mm}$ dan ketebalan yang terbesar pada perlakuan X2 $=$ proporsi air cucian beras $25 \%$ : air kelapa $75 \%$ ketabalan sebesar 9,05mm. Dari analisis ragam menunjukkan bahwa perbedaan proporsi pada Nata de Leri memberikan pengaruh yang sangat nyata terhadap ketebalan Nata de Leri.

Ketebalan nata de leri yang dihasilkan cenderung meningkat seiring dengan adanya nutrisi tambahan seperti protein, lemak, mineral dan vitamin dari air kelapa maupun leri yang mampu menstimulasi perubahan gula menjadi selulosa oleh acetobecter xylinum. Pembentukan selulosa oleh acetobecter xylinum memerlukan gula sebagai unsur utama protein dan lemak sebagai senyawa perantara, serta mineral sebagai penstimulasi dalam pembentukan selulosa (Moat dan foster1988). Ketebalan nata pada perlakuan $25 \%$ cucian beras : $75 \%$ air kelapa memeiliki ketebalan tertinggi disebabkan adanya penambahan nutrisi yang 
cukup untuk pertumbuhan acetobacter xylinum.

KETEBALAN NATA DE LERI

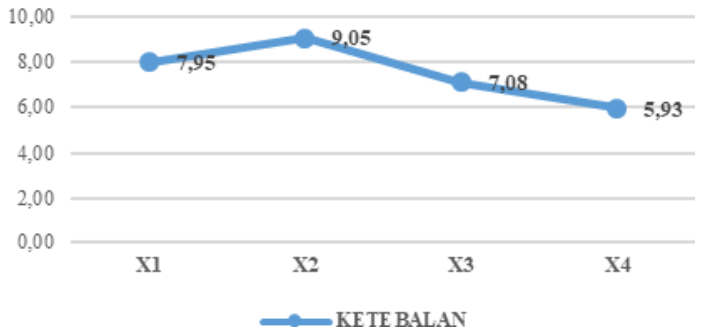

Gambar 1 Rata-rata hasil analisa ketebalan nata de leri

\section{Analisa Organoleptik}

Pengujian organoleptik adalah uji penerimaan (preference test), yaitu uji hedonik. Tujuan uji ini adalah untuk mengetahui apakah suatu komoditi dapat diterima oleh masyarakat, panelis diminta tanggapan tentang kesukaan atau ketidaksukaan pada komoditi tersebut (Afriani, 2011). Uji organoleptik terhadap Nata de Leri dilakukan oleh 20 orang panelis. Produk yang diujikan terdiri dari 4 sampel Nata de Leri dengan perlakuan berbeda. Pengujian meliputi Tekstur, aroma dan warna.

\section{Tekstur}

Dari hasil produk Nata de Leri menghasilkan nilai kesukaan panelis pada uji tekstur berkisar antara 1,5 (tidak suka) sampai dengan 2,6 (suka). Berdasarkan analisis statistik proporsi air cucian beras dan air kelapa terhadap tekstur Nata de Leri ada beda nyata ( $\mathrm{x} 2$ tabel $<\mathrm{x}$ hitung).

Nilai kesukaan panelis pada uji organoleptik tekstur menunjukkan nilai terendah pada perlakuan proporsi air kelapa $0 \%$ dan air cucian beras $100 \%$ X4 dengan nilai 1,5 (tidak suka) sementara nilai tertinggi terdapat pada perlakuan proporso air kelapa $100 \%$ dan air cucian beras $0 \%$ X1 dengan nilai 2,6 (suka). Gambar 2 menunjukkan, kesukaan panelis terhadap tekstur Nata de Leri dengan perlakuan proporsi air kelapa $100 \%$ dan air cucian beras $0 \% \mathrm{X} 1$. Hal ini dikarenakan tekstur dari perlakuan tersebut tidak terlalu kenyal dan tidak terlalu lembek, serta dapat mempertahankan tekstur dari Nata de Leri.

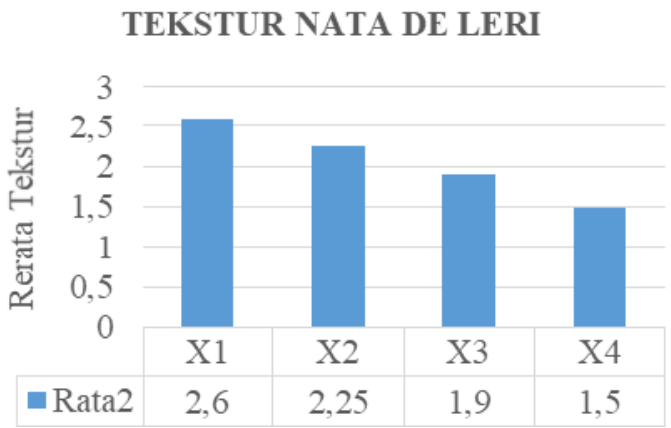

Gambar 2 Rata-rata tekstur nata de leri

\section{Aroma}

Dari hasil produk Nata de Leri menghasilkan nilai kesukaan organoleptik aroma berkisar antara 1,7 (tidak suka) sampai dengan 2,5 (suka). Berdasarkan analisis statistik proporsi air cucian beras dan air kelapa terhadap aroma Nata de Leriada beda nyata (x2 tabel $<\mathrm{x}$ hitung).

Nilai kesukaan panelis pada uji organoleptik aroma menunjukkan nilai terendah terdapat pada perlakuan proporsi air kelapa0\% dan air cucian beras $100 \%$ (X4) dengan nilai 1,7 (tidak suka) sementara nilai tertinggi terdapat pada perlakuan proporsi air kelapa $75 \%$ dan air cucian beras $25 \%$ (X2) dengan nilai 2,5 (suka). Gambar 4.3 menunjukkan kesukaan panelis terhadap aroma Nata de Leri dengan perlakuan perlakuan proporsi air kelapa75\% dan air cucian beras $25 \%$ (X2). Hal ini dikarenakan perakuan tersebut lebih disukai panelis karena aromanya tidak terlalu tajam. 
AROMA NATA LERI

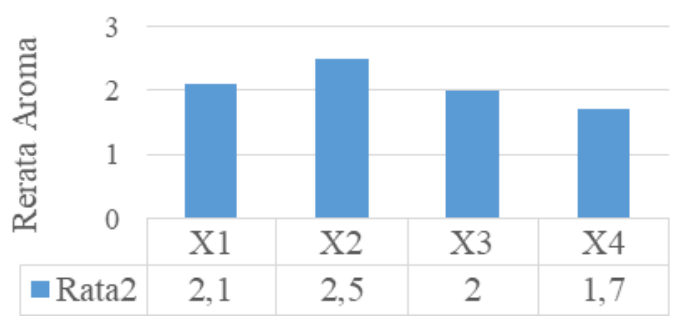

Gambar 3 Rata-rata aroma nata de leri

\section{Warna}

Dari hasil produk Nata de Leri menghasilkan nilai kesukaan pada uji organoleptik warna berkisar antara 1,65 (agak suka) sampai dengan 2,40 (suka). Berdasarkan analisis statistik proporsi air cucian beras dan air kelapa terhadap warna Nata de Leri ada beda nyata ( 2 tabel $<\mathrm{x}$ hitung).

Nilai kesukaan panelis pada uji organoleptik warna menunjukkan nilai terendah pada perlakuan proporsi air kelapa $100 \%$ dan air cucian beras 0\% (X1) dengan nilai 1,65 (tidak suka). Sementara nilai tertinggi terdapat pada perlakuan proporsi air kelapa $75 \%$ dan air cucian beras $25 \%$ (X2) dengan nilai 2,40 (suka). kesukaan panelis terhadap warna Nata de Leri dengan perlakuan proporsi air kelapa $75 \%$ dan air cucian beras $25 \%$ (X2). Hal ini dikarenakan perlakuan tersebut lebih disukai panelis yang warnanya tidak terlalu pudar .

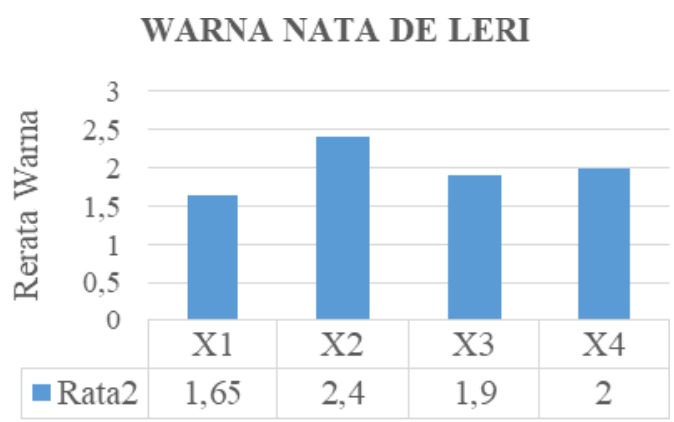

Gambar 4.4 Rata-rata warna nata de leri

\section{Perlakuan Terbaik}

Penentuan perlakuan terbaik nata de leri dilakukan dengan menggunakan metode indeks efektivitas. Metode ini dilakukan pada parameter fisik yang meliputi uji ketebalan serta uji organoleptik meliputi tekstur, aroma, dan warna. Bobot parameter tertinggi pada aroma sebesar 0,265 diikuti oleh warna sebesar 0,260,dan yang terakhir rasa sebesar 0,245. Hasil perhitungan indeks efektivitas menunjukkan kombinasi perlakuan terbaik pada X2 (air kelapa75\% dan air cucian beras $25 \%$ ) yaitu, ketebalan 9,05mm, tekstur dengan nilai 2,25 (agak suka), aroma dengan nilai 2,50 (suka), warna dengan nilai 2,40 (suka).

\section{PERLAKUAN TERBAIK}

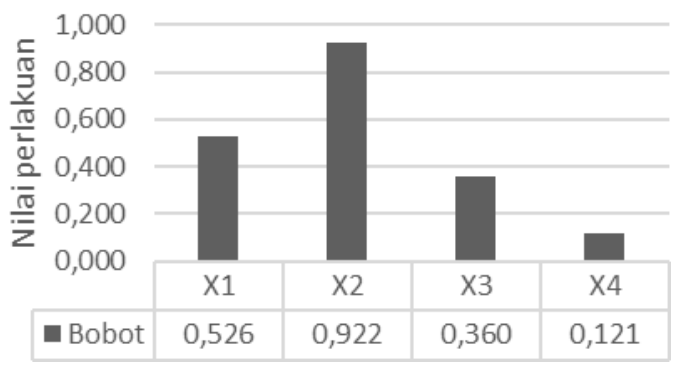

\section{KESIMPULAN DAN SARAN}

\section{Kesimpulan}

1. Proporsi air cucian beras dan air kelapa terbaik dari sifat fisik dengan hasil analisa uji ketbalan nata de leri terdapat pada perlakuan X2 (air kelapa 75\% dan air cucian beras 25\%) dengan nilai ketebalan $9,05 \mathrm{~mm}$.

2. Proporsi air cucian beras dan air kelapa terbaik dari sifat organoleptik dengan uji indeks efektivitas terdapat pada perlakuan X2 (air kelapa 75\% dan air cucian beras $25 \%$ ), dengan nilai 2,25 (agak suka), aroma dengan nilai 2,50 (suka), warna dengan nilai 2,40 (suka).

3. Proporsi air cucian beras dan air kelapa terbaik dari sifat fisik dan organoleptik dengan uji indeks efektivitas terdapat pada perlakuan X2 (air kelapa 75\% dan 
air cucian beras $25 \%$ ), dengan nilai 2,25 (agak suka), aroma dengan nilai 2,50 (suka), warna dengan nilai 2,40 (suka).

\section{Saran}

. Untuk kesempurnaan dan pengembangan hasil penelitian ini maka disarankan:

1. Perlu melakukan penelitian kandungan yang lain dari air cucian beras dan air kelapa dengan menggunakan metode yang berbeda.

2. Perlu melakukan pengujian analisis sifat kimia nata de leri meliputi kadar air, kadar serat,kadar lemak,kadar protein dan kadar vitamin B1 pada nata de leri.

\section{DAFTAR PUSTAKA}

Afriani, Suryono dan Lukman Haris. 2011. Karakteristik Dadih Susu Sapi Hasil Fermentasi Beberapa Starter Bakteri Asam Laktat Yang Diisolasi Dari Dadih Asal Kabupaten Kerinci. Jurnal Agrinak. 1 (1).
Arviyanti, Erlina., Yulimartani, Nirma. 2009. Pengaruh Penambahan Air Limbah Tapioka pada Proses Pembuatan Nata. Seminar Tugas Akhir S1. Teknik Kimia. UNDIP: Semarang

Fitriah, L. 2009. Pemanfaatan Air Cucian Beras sebagai Bahan Pembuatan Nata. (Seminar Kimia) Fakultas FMIPA Ilmu Keguruan dan Ilmu Pendidikan Mataram

Moat, A. G. \& J. W. Poster. 1988 Microbial Physiology 2nd ed. John Wiley \& Sons Inc. Toronto.

Nugraheni, M. 2007. Nata dan Kesehatan. Fakultas Teknik UNY: Yogyakarta

Nur, A 2009. Karakteristik Nata de Cottoni dengan penambahan dimetil amino fosfat (DAP) dan asam asetat glacial. Skripsi Institut Pertanian Bogor

Rachmat,A Agustina, F. 2009. Pembuatan Nata de coco dengan fotifikasi limbah cucian beras menggunakan Acetobacter Xylinum. UNDIP Semarang 